\title{
Status Effect on Children Outside Married Status After Constitutional Religious Court Decision
}

\author{
Sulaiman*) \\ $\left.{ }^{*}\right)$ Sulaiman, SH., M.Kn \& Partners, Kendari, Indonesia, E-mail: udmaharani@gmail.com
}

\begin{abstract}
The purpose of this study as follows 1) To identify and explain Child outside influence married status of the right to inherit after the Constitutional Court decision No. 46/PUU-VIII/2010 in the Religious Court Kendari, 2) To identify and explain the barriers outside the married status of children of the right to inherit after the decision of the Constitutional Court Number 46/PUU-VIII/2010 in the Religious Court Kendari, 3) To identify and explain solutions to overcome barriers outside the married status of children of the right to inherit after the decision of the Constitutional Court Number 46/PUU-VIII/2010 in the Religious Court Kendari. The method used by researchers is sociological approach juridical law and specification in this study were included descriptive analysis. The sources and types of data in this study are primary data obtained from field studies with interview Religious Court Judge in Kendari. And secondary data obtained from the study of literature. Based on the results of the research are In terms of inheritance after the court ruling, the position of a child outside of married as intended by the constitutional court decision outside the married is not the same child with the natural child, has been gaining street or space to get recognition for the sake of protection of the rights of the child outside the married. In this case the Constitutional Court to decide Article 46/PUU-VIII/2010 on children outside of married, deserved to be recognized by the biological father and is also entitled to inheritance equal to the other children. Constraints in this Constitutional Court decision is a matter of perspective among law enforcement and government officials to give up the rights to illegitimate children are no different treatment or other discriminatory treatment.
\end{abstract}

Keywords: Status; Children Outside Married; Religious Court; Decision.

\section{INTRODUCTION}

Children are human beings who have human values can not be eliminated by any reason. Once the importance of the child's existence in human life, then Allah rules their wedding. The rule of marriage has a purpose, among others, to reproduce (have children) is good, preserve Nasab (Blood line), avoid illness and create sakinah (Confort). Marriage family is an important event in human life which creates legal effect either on the relationship between the parties married it alone, or with others who have a particular interest. If the child born of the marriage, then the resulting legal relationship between a child and his parents. As a citizen of every child is entitled to grow in accordance with their nature as creatures of God. Children are entitled to education, care, guidance so that it becomes an adult. According to the CRC that child 
means every human being below the age of 18 years even Act No. 23 of 2002 on the Protection of the Child defines a child from inside the womb to better provide comprehensive protection of children. ${ }^{1}$

In contrast, children also have obligations to their parents, who provided for in Article 46 of Marriage Act No. 1 of 1974, the children are obliged to respect their parents and obey the will of those who are good, and if the child has grown up he is obliged to maintain according to his ability, parents and family in a straight line upwards, when they need help. This proves the existence of a legal relationship with the emergence of rights and obligations between parents and children of a Child marriage is also one of the heirs entitled to receive an inheritance. Both boys and girls are the heirs of their parents, even he is closest heir to the deceased. Inheritance relationships between parents and children is based on their relationship by blood or also called Nasab relationship, because there has been a biological relationship between husband and wife in the marriage bond, and then the child was born. However, the problem here is a child born outside marriage/wedding

Outside child children marry other than adultery and discordant child will have a civil relationship (inheritance rights) with his father and mother through recognition as stated in the Civil Code. Recognition of the child can be done in several ways like an authentic deed before marriage, along with in accomplishing the marriage, made by an employee of the civil records were registered in the register of births. ${ }^{2}$

Beyond married child population in administrative law are also entitled to get a birth certificate as legitimate children in general, but because of the provisions of Article 43 paragraph (1) of the Marriage Law Jo. Article 100 Compilation of Islamic Law which states that a child outside marriage have a civil relationship with her mother and her mother's family, it has implications for the ways and mechanisms of registration of birth certificates for children outside of marriage. On the outside the child's birth certificate will mate only mentioned her name only, while the father's name will not be recorded in the birth certificate of the child. The dissolution of the legal relationship between the child with his biological father resulted in the father does not have the obligation anything against her, and vice versa child is not entitled to claim any of the father relating to civil rights.

\section{RESEARCH METHODS}

In this study the juridical sociological research methods used by the author is the case study method. Provides that case studies is a strategy that is more suitable when the principal question to one study, when researchers have little opportunity to control the events that will be investigated, and where the focus of his research lies in the phenomenon of contemporary (present) within the context of real life. ${ }^{3}$ Specifications research used in this study is a descriptive analysis, from this study is expected to obtain a detailed and systematic description of the problem to be studied. The analysis

\footnotetext{
${ }^{1}$ Hilman Hadikusuma. (1995). Hukum Perkawinan di Indonesia. Mandar Maju, Bandung, p. 10. ${ }^{2}$ Act. No. 1 of 1974 Marriage and The Gazette of the Republic of Indonesia of 1975 No. 12.

3 Robert K. Yin. (2008). Case Studies, Design and Methods, Issue 1, print. 12, RajaGrafindo Persada, Jakarta, p. 37
} 
is meant by an idea, facts obtained will be analyzed carefully to address the problem. ${ }^{4}$ Even sources and types of data in this study are primary data obtained from field studies with interview Religious Court Judge in Kendari, and secondary data obtained from the study of literature.

\section{RESULT AND DISCUSSION}

\subsection{Effect of Children Outside Married against Inherited Rights After Constitutional Court Decision No. 46/PUU-VIII/2010 in the Religious Court Kendari}

Child rights are part of human rights must be upheld and protected by parents, community, and country. Various facilities should be provided to ensure the growth and development of children in an optimal and targeted. ${ }^{5}$ The fulfillment of these rights are implemented without discrimination. ${ }^{6}$

Article 27 paragraph (1) of the 1945 Constitution requires all citizens shall be equal before the law. CRC (Convention on the Rights of the Child) also requires that every child should be respected and guaranteed their rights without discrimination in any form without regarded to race, color, sex, language, religion, creed, race, ethnicity, wealth, birth or other position of the child or the child's parents or caregivers are legitimate, then the rights of the child outside the married is also guaranteed without discrimination. ${ }^{7}$

Discrimination against civil rights to children outside of married is not aligned with the principles of the concept of human rights. Article 1 of the Universal Declaration of Human Rights (UDHR), stated that all people are born free and have the dignity and the same rights. They are endowed with reason and conscience and should associate with one another in the fraternity. ${ }^{8}$ Article 2 states that everyone is entitled to all the rights and freedoms set forth in this Declaration, with no exceptions whatsoever, such distinction as to race, color, sex, language, religion, political or other views, national origin or social, property, birth or other position. Specifically Article 25 paragraph (2) of the Universal Declaration states that mothers and children are entitled to special care and assistance. All children, whether born in or out of wedlock, shall enjoy the same social protection. ${ }^{9}$ Declaration of Rights of the Child also requires that children should enjoy all the rights only, without discrimination because of race, color, sex, language, religion, political or other views, national origin or social, property, birth, or social

\footnotetext{
${ }^{4}$ Sunaryati Hartono. (1994). Indonesia Legal Research At the end of the 20th century, Alumni, Bandung. p. 101.

${ }^{5}$ HM Hasballah Thaib and Faith Jauhari. (2004). Capita Selecta Hukum Islam, Perpustakaan Nasional Press, Medan, p. 5

${ }^{6}$ Andi Syamsu Alam and M Fauzan. (2008). Adopsi dalam Hukum Islam, Kencana Prenada Media Group, Jakarta, p. 1.

${ }^{7}$ Article 1 of the UN Convention on Child Rights

${ }^{8}$ Article 1 of the Universal Declaration on Human Rights

${ }^{9}$ Nasir Djamil. (2013). Child Not for Condemned: Notes Discussion Juvenile Justice System Law, Sinar Grafika, Jakarta, p. 26.
} 
status the other, both he and his family; Every child should be protected from any practice of discrimination based on racial, religious and other forms. ${ }^{10}$

Likewise, the concept of justice put forward Majid Khadduri ${ }^{11}$ where civil rights were acquired by the illegitimate child of his biological father after the Constitutional Court Decision No. 46/PUU-VIII/2010 was issued. In addition it seems fair that provides a decent living for the child not only for the child's mother-father alone but also have obligations. In connection with Constitutional Court Decision No. 46/PUUVIII/2010 dated 17 February 2012, in dictum reviewing the provisions of Article 43 paragraph (1) of Act No. 1 of 1974 marriage becomes;

"Children born out of wedlock have a civil relationship with her mother and her mother's family, and with his father as a man who can be proved by science and technology and/or other evidence according to the law have blood relations, including civil relations with his father's family."

According to Mr. Abd. Farih, $\mathrm{SH} ., \mathrm{MH}$, as the judge in the Religious Court Kendari ${ }^{12}$ that there is a relationship minimal legacy Nasab (humanity)/fairness most part $1 / 3$ and should not be detrimental to other heirs.

Inheritance rights for children outside of married after the Constitutional Court Decision No.46/PUU-VIII/2010: In the case of inheritance after the court ruling, the position of a child outside of married as intended by the constitutional court decision outside the married is not the same child with bastard, has been gaining street or space to get recognition for the sake of protection of the rights of the child outside the married. Then the equation outside child marriage mate and children through legitimate rights and equal protection, the only difference being how they have the same rights and protections. In this case the Constitutional Court to decide Article 46/PUU-VIII/2010 on children outside of married, deserved to be recognized by the biological father and is also entitled to inheritance equal to the other children.

\subsection{Barriers Status Married Children Affairs of the Rights of Inheriting After- Decision Constitutional Court Number 46/PUU-VIII/2010 in the Religious Court Kendari}

How to calculate the absolute section should observe the provisions of Article $916 \mathrm{~A}$ of the Civil Code. Under the terms of that Article, in terms of absolute no heirs and the heirs are not absolute, gifting must not violate the absolute section is specified. Determination of the absolute part regardless of any heir is not absolute. Outside child heir marries absolute categorized by Constitutional Court Decision No. 46/PUUVIII/2010 for children outside of the married obtain recognition of the biological father or past legal actions in court. And if it exceeds the amount gifting absolute part determined without taking into account the heir is not absolute, the excess can be reclaimed by the heirs of the absolute.

\footnotetext{
${ }^{10}$ Maidin Gultom. (2012). Legal Protection Against Children and Women, Refika Aditama, Bandung, p. 103.

${ }^{11}$ Khadduri, Justice Theology, p. 119-201.

${ }^{12}$ Interviews with Drs. Tahir, SH., MH, as the judge in the Religious Kendari, on December 23, 2019, 10:45 pm
} 
According to the explanation of Prof. Ali Afandi, the purpose of provisions of Article 916 A of the Civil Code is that the heir is not absolute protection of the heirs of the absolute. In addition, part of the legacy absolute heirs are not harmed by gifting conducted by the heir. By not taking into account the heir is not absolute, then the absolute heir inheritance be great because of the number of heirs is diminished, as part of the absolute calculated based on the part of an heir. ${ }^{13}$ Number of absolute section also becomes large.

The growing absolute part means more narrow the possibility of grants. In this way, the absolute part that can not be reduced enough to at devided between the heirs and the heirs absolute not absolute because in calculating the section on basic wear their heirs truly. The step quantify the absolute rights in the event there is a testament to the inheritance, for example, is Heir to leave a child and a wife. Son is absolute heirs (including children outside the married After a Constitutional Court decision) and the wife is not absolute heir. Part of the child and mother are the same, part of the child is half the inheritance. ${ }^{14}$

Absolute part of the child is one-half times half the inheritance, equal to a quarter of the legacy. Thus, the legacy of which can be granted are all reduced inheritance legacy quarter, equal to three-quarters inheritance. Based on these calculations it is clear that the wife does not acquire any portion of inheritance because after deducting the absolute right (a quarter of a legacy) can be granted all the (three-quarters legacy). With the provisions of Article 916 of the Civil Code a state into another. Based on this article, since it is not an heir wives absolutely computed first as heir. Which is calculated only child (legitimate or outdoor wedding) as heirs absolute. Putting aside the earlier wives, children receive the entire inheritance.

Thus, the absolute right of a child is one-half of all inheritance. That can be granted is one-half the remaining estate, instead of three-quarters of a legacy as the first calculation. Because that can be granted is now only half the inheritance, there is still half the inheritance to the heirs, both absolute and not absolute. Half the estate was divided between wives and children. According to Article 852 a Civil Code, section by section of the wife, children, the wife gets a quarter as inheritance and child gets a quarter of its heritage.

Constraints in this Constitutional Court decision is a matter of perspective among law enforcement and government officials to give up the rights to illegitimate children are no different treatment or other discriminatory treatment.

\subsection{Solutions For Overcoming Obstacles Status Married Children Affairs of the Rights of Inheriting Following the Ruling of the Constitutional Court No. 46/PUU-VIII/2010 Religious Court of Kendari}

For the author, the Constitutional Court decision No. 46/PUU-VIII/2010 is a barrier between areas of curative and preventive region. Fate of Children extramarital happened before the decision of the Constitutional Court is trying to be more protection to be given assertions about civil rights continuity of a child out of wedlock

13 Muhammad, op.cit, p.224

14 Book of the Law of Civil Law 
to her biological father in order for the government to give sanction for any man to conceive the child in the womb of the mother so as not arbitrarily left its responsibilities as the biological father of the child. Because in any religious concept, the term original sin is not known.

According to Imam Musthofa, cancellation applicability of Article 43 paragraph (1) of Act No. 1974 marriage aims: 1) Giving legal entity blood relationship between the child and her biological father, namely that the blood relationship between the child's biological father was originally just a reality of a legal relationship that has legal consequences. 2) Provide legal protection of the fundamental rights of children, both against his father and his father's family and the environment. 3) Provide equitable treatment of every child born despite marital parents are not (yet) no certainty. 4) Reaffirming their civil relationship with each child's biological father and his father's family in accordance with the law as a civil relationship with her mother and her mother's family. 5) Reaffirming their obligations under the law's father (legal custady) maintain every child born of his blood. 6) Protect children from his father's inheritance rights for their blood relations, rights and responsibilities to one another. 7) To ensure the future of children as children in general. 8) Ensure the child's right to receive the care, maintenance, education and cost of living, protection and others from his father as they should. 9) Give firmness law that every man should be responsible for their actions and the consequences arising from the offense, in this case led to the birth of children. They can not escape that responsibility. 9) Give firmness law that every man should be responsible for their actions and the consequences arising from the offense, in this case led to the birth of children. They can not escape that responsibility. 9) Give firmness law that every man should be responsible for their actions and the consequences arising from the offense, in this case led to the birth of children. They can not escape that responsibility. ${ }^{15}$

After giving a solution (or at least provide legal certainty) to a child out of wedlock who were born after the release of the decision of the Constitutional Court Number 46/PUUVIII/2010 was (curative), the Court seeks the decision of the Court in order to prevent cases of the same does not happen again. It is not the effort of the Court to legalize adultery. But rather an effort to prevent the Court in order to prevent (or can be said to suppress) cases of the birth of a child outside of marriage, in addition to sanctioning or with language software is to give responsibility for the biological father to the survival of children (out of wedlock) it.

\section{CLOSING}

\subsection{Conclusion}

In terms of inheritance after the court ruling, the position of a child outside of married as intended by the constitutional court decision outside the married is not the same child with the natural child, has been gaining street or space to get recognition for the sake of protection of the rights of the child outside the married. Then the equation outside child marriage mate and children through legitimate rights and equal

\footnotetext{
${ }^{15}$ Imam Mustafa. (2012). "The Impact of the Constitutional Court Decision Regarding Article 43 Paragraph (1) of Act No. 1 of 1974 Marriage Law Against Family In Indonesia, " Al-Manahij: Journal of Islamic Legal Studies 6, no. 2, p. 291.
} 
protection, the only difference being how they have the same rights and protections. In this case the Constitutional Court to decide Article 46/PUU-VIII/2010 on children outside of married, deserved to be recognized by the biological father and is also entitled to inheritance equal to the other children.

\subsection{Suggestion}

As for the inheritance rights of children outside biological father marry against property remained generally taken into account although it did not gain the right to inherit. If the presence of children outside the married recognized by the man who is not the biological father, then still be calculated and will get the inheritance of men.

\section{REFERENCES}

Journal:

Imam Mustafa. (2012). "The Impact of the Constitutional Court Decision Regarding Article 43 Paragraph (1) of Act No. 1 of 1974 Marriage Law Against Family In Indonesia, "Al-Manahij: Journal of Islamic Legal Studies 6, no. 2, p. 291.

Books:

Andi Syamsu Alam and M Fauzan. (2008). Adopsi dalam Hukum Islam, Kencana Prenada Media Group, Jakarta

Hilman Hadikusuma. (1995). Hukum Perkawinan di Indonesia. Mandar Maju, Bandung

HM Hasballah Thaib and Faith Jauhari. (2004). Capita Selecta Hukum Islam, Perpustakaan Nasional Press, Medan

Maidin Gultom. (2012). Legal Protection Against Children and Women, Refika Aditama, Bandung

Nasir Djamil. (2013). Child Not for Condemned: Notes Discussion Juvenile Justice System Law, Sinar Grafika, Jakarta

Robert K. Yin. (2008). Case Studies, Design and Methods, Issue 1, print. 12, RajaGrafindo Persada, Jakarta

Sunaryati Hartono. (1994). Indonesia Legal Research At the end of the 20th century, Alumni, Bandung.

Regulations:

Article 1 of the UN Convention on Child Rights

Article 1 of the Universal Declaration on Human Rights

Book of the Law of Civil Law

Act No. 1 of 1974 on Marriage

The Gazette of the Republic Indonesia of 1975 Number 12.

Interview:

Interviews with Drs. Tahir, $\mathrm{SH} ., \mathrm{MH}$, as the judge in the Religious Kendari, on December 23, 2019, 10:45 pm 